\title{
2007: A Canadian Corporate Ownership Survey ${ }^{1}$
}

\author{
Calin Valsan ${ }^{2}$
}

\begin{abstract}
This study documents a decline in the levels of corporate ownership concentration between 1996 and 2007. When compared to previous studies, the incidence of ownership stakes of $20 \%$ or larger has decreased form $60 \%$ to $41 \%$ of the total population of publicly listed Canadian firms. Regional disparities among provinces remain important. Ontario, Alberta, and British Columbia have the most widely-held firms, while Quebec and Atlantic Canada show the most concentrated corporate ownership patterns. The interpretation of these results requires a complex understanding of historical, demographic, cultural, political and institutional factors.
\end{abstract}

JEL classification: F52, G32, K22, L25, O51, P16

Keywords: Canada, corporate ownership, corporate governance, blockholder, ownership stake, ownership concentration

\section{Introduction}

This present study employs a very recent and large sample of TSX listed firms and aims to re-evaluate the empirical evidence on corporate ownership in Canada. It is shown here that blockholding remains rather common, yet the widely-held firm has become more prevalent over the last ten years ${ }^{3}$. Regional disparities persist, but unlike previous studies that single out Quebec, this one finds that Eastern Canada as a whole (including Quebec) displays a more pronounced tendency towards concentrated ownership. We define blockholders as shareholders who control $10 \%$ or more of the total votes of the firm. A footnote on CEO compensation suggests that payperformance is lower for closely held firms and for very large firms as measured by the size of their assets. Previous studies have interpreted their findings mainly by making reference to law regimes, taxation, and corporate governance regulation. Here, we acknowledge the insight of Bebchiuk and Roe (1999) with respect to path dependence, and we conjecture an explanation based on the eclectic interaction among economic, political, geographic, cultural, and institutional factors.

This study is organized as follows. Section two provides a brief discussion of the literature. Data is presented in section three. Empirical results are presented in sections

\footnotetext{
1 The author graciously acknowledges the University of New Brunswick Saint John for providing access to research facilities during the author's sabbatical leave and Bishop's University Senate Research Committee for providing financial support. Many thanks to Pascal Robert, Melissa Glickman, Mathieu Huard, Andreas Reissner, Joshua Henessy, Tomas Gauthier, and David Jenkins who collected the data that made this research possible. Insightful comments have been provided by Linda and Kurt Hansen.

2 Williams School of Business, Bishop's University, Lennoxville, Sherbrooke - Quebec J1M 1 Z7 - (819) 822-9600/2448 - cvalsan@ubishops.ca

3 A handful of studies began only recently to systematically investigate corporate ownership patterns in Canada [Morck et al. (2000), Morck and Yeung (2004), Attig et al. (2004), Bozec and Laurin (2004, 2006), and Gadhoum (2006)]. Using data from the mid-1990s, they found that Canadian corporations are far less widely held than their American or British counterparts.
} 
four through eight. A brief discussion and interpretation of results is provided in sections nine. Section ten concludes.

\section{The Current Record on Corporate Ownership in Canada}

The commentators of Canadian economic history have always noted the concentration of economic power in the hands of a small yet influential elite. This view made its way into mainstream culture through the works of historians, such as Naylor (1975), Bliss (1986), Norrie and Owram (1991), and Taylor and Baskerville (1994), and through the accounts published by columnists such as Peter C. Newman (1977, 1991, and 1998) and Diane Francis (1986, 2008).

Recently, a handful of academic studies provide a systematic review of the empirical evidence on Canadian corporate ownership. This line of research has emerged in the 1990s, and builds on the increasing interest shown towards the understanding of various systems of corporate finance within the larger framework provided by legal systems, culture, tradition, and religion. La Porta et al. $(1998,1999)$ provide two landmark studies; the authors attempt to tally and compare various corporate governance arrangements around the world. The primary motivation of this approach was to raise awareness that outside the United States and Britain the modern corporation did not quite match the widely-held ownership model advanced by Adolf Bearle and Gardiner Means (1932), and popularized by John Kenneth Galbraith (1971) and Alfred Chandler (1977); hence, many corporate governance scholars set out to document and debate this intriguing state of affairs [Zingales (1994), Schleifer and Vishny (1997), Becht and Roell (1999), Claessens et al. (2002), Faccio and Lang (2002), Anderson and Reeb (2003), Denis and McConnell (2003), Nenova (2003), Stulz and Williamson (2003), and Dyck and Zingales (2004)].

La Porta et al. (1999) report high ownership concentration for a small sample of Canadian corporations. Using data from the same historical period, Gadhoum (2006) and Bozec and Laurin (2004 and 2006) confirm these findings. About 60\% of Canadian firms publicly traded in the mid-1990s have ownership stakes of $20 \%$ or higher. These two latter studies warrant our close attention because they take a more nuanced look at regional ownership structures. There appears to be a certain degree of differentiation between Quebec and the rest of the country. Up to $80 \%$ of Quebec firms show ownership stakes at the $20 \%$ cut-off. These regional differences are attributed to the particularities of the civil law regime, following the insights provided by La Porta et al. (1998). Bozec and Laurin (2006) note that Quebec firms are subject to conflicting regulation: they must comply with both provincial and federal corporate laws. While the Canada Business Corporations Act is very similar to other common-law legislation in terms of investor protection, the Companies Act of Quebec is less stringent than its federal counterpart.

Morck et al (2000) associate the concentration of ownership with lower productivity growth and sub-par economic performance. They even coin a new term for this predicament, calling it the "Canadian disease." There are several other similar studies that analyze corporate performance in relation to ownership. [Eckbo and Thorburn (2000), André et al. (2006), and Ben Amar and André (2006)]. 
A concise, yet insightful historical account of corporate ownership in Canada is provided by Morck et al (2003). The authors make several contentions that elucidate to some extent the nature of Canadian capitalism. First, Canadian corporations have their roots in a tradition of mercantilism going back to the colonial era predating the Confederation. Second, domestic taxation of inheritances played a major role in the rise and subsequent decline of the widely-held firm. Third, the re-emergence of the mercantilist state in the 1970s in the form of Trudeau-style dirigisme has favored closely-held over widely-held firms because the former category proved more apt in dealing with the omniscient government bureaucracy. Under the cover of promoting a marked nationalistic agenda (which has long been a part of the Canadian political discourse), the capitalist elite re-asserted its control over the Canadian economy in exchange for support for the welfare state. In the end, Morck et al (2003) muse over the apparent quandary surrounding Canadian corporate ownership: pyramids and concentrated ownership structures are usually associated with developing countries and low-trust economic settings, because they supplant investor rights and reduce the scope for other moral hazards. Canada is not, however a developing country. The quality of its institutional framework is as good as in UK, for example, yet corporate ownership patterns are dramatically different [Attig and Gadhoum (2003)]. One has to conclude that the only explanation one could advance here pertains to the nature of private benefits of control associated with large shareholders [Barclay and Holderness (1989)].

Citing several regulatory anachronisms, Morck and Yeung (2006) plead for a substantial reform of corporate governance in Canada. The authors blame the dividend tax regime, dual-class shares, and other regulation causing a substantial incongruence between cash flow and control rights. As such, corporate governance in Canada is at grips with two types of agency conflicts: one pitting managers against shareholders, and the other pitching blockholders against smaller shareholders.

There is no doubt that globalization and financial liberalization must have certainly played an important role in increasing the awareness of and curiosity towards comparative corporate governance systems. A majority of studies cited earlier would have not been possible a quarter of a century ago. World-wide liberalization of trade and finance has contributed to a relative convergence of economic systems. Paradoxically, this increase in openness has brought to the fore the glaring differences that remain among various systems of corporate finance. A certain leveling of the playing field has lightened the task of studies endeavoring to identify salient factors that make a difference in corporate governance.

Most studies on Canadian corporate ownership use 1996 data. The size of the samples used is rather small, with one notable exception [Gadhoum (2006)]. Studies employing data collected before or during 1996 might have missed some of the timelagged effects induced by the latest wave of financial liberalization and economic globalization that started in earnest in the early 1990s. It is only legitimate to presume that these trends might have had a conspicuous impact on Canada. As it will be shown later, our main results corroborate earlier findings, but also reveal a trend towards an increase in wider-held ownership across the board. 


\section{Data}

The sample used here consists of 1,452 firms listed on the Toronto Stock Exchange in the spring of 2007. The data include financial, ownership, and various corporate governance information.

Financial information pertains to total assets, liabilities, revenue, and market capitalization. The sources of data are the most recent annual reports (end of 2006) filed with the Ontario Securities Commission, provided by the System for Electronic Document Analysis and Retrieval (SEDAR). Total and long-term debt ratios are estimated by dividing total debt and long-term debt respectively by total assets. Sales to assets ratios are calculated by dividing annual sales by total assets. ROA and ROE is calculated by dividing net income by total assets and owner's equity. Average market capitalization is estimated by taking the average of the previous 52 weeks low and high stock prices, multiplied by the number of outstanding shares. Market-to-book ratios are calculated by dividing average market capitalization by owner's equity.

Data on ownership is obtained from the most recent management proxy circular. This circular usually indicates the significant blockholders and the size of their stake. Blockholders are shareholders who control $10 \%$ or more of the total votes of the firm. We need to know who owns $10 \%$ or more of total votes in order to calculate cumulative blockholder (ownership) stakes. Cumulative blockholder (ownership) stakes are estimated by adding the votes of all blockholders in each firm. For example, if a firm has two blockolders controlling $13 \%$ and $16 \%$ of votes respectively, then cumulative blockholder ownership equals $29 \%$.

While it is usual to use both $10 \%$ and $20 \%$ cutoff points as thresholds of cumulative ownership concentration, here we focus only on the $20 \%$ cutoff because it is more stringent and produces more conservative estimations. The number of firms with $20 \%(50 \%)$ ownership stakes is simply calculated by counting the number of firms in which cumulative blockholder (ownership) stakes account for at least 20\% (50\%) of total votes. The average number of votes per share has been obtained by dividing the total number of votes by the total number of shares, regardless of their class. For example, if a company has 1 million class-A shares with ten votes each and 20 million class-B shares with one vote each, the number of average votes per share equals 1.43 (10 million votes +20 million votes $) /(21$ million shares $)$.

Several studies have attempted to establish the nature and identity of the ultimate owners, either by examining direct ownership stakes, or by following the control thread across pyramidal ownership structures [(La Porta et all (1999), Attig et al (2004), Bozec and Laurin (2006)]. Unarguably, this approach has many merits, but also some potential pitfalls. In many instances, control can be exercised indirectly, through interlocking shareholdings and through many smaller stakes that do not make the $10 \%$ cutoff, and hence go unreported. For the sake of consistency and conservatism, this study counts only direct ownership stakes reported in the management proxy circular. While it might conceivably underestimate the extent of ownership concentration and its complexity, it calculates firm and reliable lower limits to its magnitude.

As well, data on corporate governance is obtained from the most recent management proxy circular as well. CEO cash pay is estimated by aggregating base 
salaries and cash bonuses. CEO performance pay is estimated by aggregating the value of stock options and restricted shares granted.

The total number of TSX listed firms is slightly larger than 1,452. Corporations in the process of being de-listed, amalgamated, dissolved, spun-off, or under bankruptcy proceedings were excluded from the final sample. In the case of several observations, financial, ownership, or governance information is partially missing, either because it is not being disclosed, or because it does not appear accurate when cross-checked against other sources, such as the Financial Post and the System for Electronic Disclosure by Insiders (SEDI).

\section{Results}

Table 1 presents several ownership statistics by province. Overall, $41 \%$, or 600 of the total 1,452 TSX listed firms show combined ownership stakes of $20 \%$ or more (Table 1, Panel A). A number of 288 of the total 1,452 firms have blockholders in uncontested control of their corporations, commanding $50 \%$ or more of total votes. The average cumulative blockholding stake is $23 \%$, while the median is only $13 \%$. The board of the average TSX-listed firm has about six members, of which four are classified as "independent." The CEO of the average firm is paid about $\$ 1.5$ million in annual compensation, of which about $80 \%$ is performance pay. The median CEO receives roughly $\$ 430,000$ annually, of which about $70 \%$ is performance pay. As easily noted, the distribution of data (according to an overwhelming majority of characteristics) is very skewed, with one exception: board size.

The largest province, Ontario leads the country as the preferred destination of Canadian corporations. Slightly under 700 firms, or almost half of the entire population of TSX listed firms are headquartered there. In the last 30 years, Ontario has become the economic engine of Canada, and it is not surprising to see such a large proportion of listed firms in this province. Alberta trails Ontario as the second largest province of destination for publicly listed TSX firms; it is home to 281 corporations. British Columbia occupies the third place with 191, and Quebec comes in the fourth place, with only 159 firms. The prairies provinces and Atlantic Canada are home to another 55 firms. The difference between these numbers and the total of 1,452 is represented by foreign listings.

According to this paper's estimation, the domestic market capitalization of the TSX edged above $\$ 2,000,000,000,000$ in 2006/2007 (Table 1, Panel B). This figure has been estimated by adding the average market capitalization of all domestic firms. Ontario accounts for almost half of the domestic market capitalization of the TSX. Firms headquartered in Alberta account for 28\%, and Quebec firms account for only $11 \%$. The combined market capitalization of Albertan firms is almost two and a half higher than that of Quebec firms. 
Table 1. Panel A: TSX listed firms by province.

\begin{tabular}{|c|c|c|c|c|c|c|c|}
\hline & $\begin{array}{l}\text { No. of } \\
\text { firms }\end{array}$ & $\begin{array}{l}\text { Cumulative } \\
\text { blockholder } \\
\text { votes per firm } \\
\%\end{array}$ & $\begin{array}{l}\text { Number of } \\
\text { firms with } \\
20 \% / 50 \% \\
\text { cumulative } \\
\text { ownership } \\
\text { stakes }\end{array}$ & $\begin{array}{l}\text { Directors/of } \\
\text { which } \\
\text { independent }\end{array}$ & $\begin{array}{l}\text { Executive } \\
\text { share } \\
\text { holding } \\
\%\end{array}$ & $\begin{array}{l}\text { CEO cash } \\
\text { pay } \\
(\$ \text { mil })\end{array}$ & $\begin{array}{l}\text { CEO } \\
\text { performance } \\
\text { pay } \\
(\$ \mathrm{mil})\end{array}$ \\
\hline British Columbia & 191 & & & & & & \\
\hline Mean & & $23.8 \%$ & $78 / 33$ & $5.9 / 4.3$ & $1.97 \%$ & $\$ 0.52$ & $\$ 0.63$ \\
\hline Median & & $14.8 \%$ & - & $6 / 4$ & $0 \%$ & $\$ 0.16$ & $\$ 0.21$ \\
\hline Standard deviation & & $27.5 \%$ & - & $2.5 / 2.3$ & $5.4 \%$ & $\$ 1.3$ & $\$ 0.87$ \\
\hline Alberta & 281 & & & & & & \\
\hline Mean & & $17.9 \%$ & $92 / 36$ & $6.3 / 4.6$ & $10 \%$ & $\$ 0.35$ & $\$ 1.2$ \\
\hline Median & & $10 \%$ & - & $6 / 5$ & $0 \%$ & $\$ 0.15$ & $\$ 0.3$ \\
\hline Standard deviation & & $25.4 \%$ & - & $2.6 / 2.5$ & $124.9 \%$ & $\$ 0.7$ & $\$ 2.6$ \\
\hline $\begin{array}{l}\text { Manitoba and } \\
\text { Saskatchewan }\end{array}$ & 27 & & & & & & \\
\hline Mean & & $31.4 \%$ & $12 / 10$ & $7 / 5.7$ & $0.22 \%$ & $\$ 0.18$ & $\$ 1.6$ \\
\hline Median & & $18.1 \%$ & - & $6 / 4$ & $0 \%$ & $\$ 0.4$ & $\$ 1.3$ \\
\hline Standard deviation & & $33.15 \%$ & - & 3.93 .6 & $0.6 \%$ & $\$ 0.8$ & $\$ 1.9$ \\
\hline Ontario & 692 & & & & & & \\
\hline Mean & & $21.6 \%$ & $269 / 133$ & $5.7 / 4$ & $1.7 \%$ & $\$ 1.9$ & $\$ 0.96$ \\
\hline Median & & $10.8 \%$ & - & $6 / 4$ & $0 \%$ & $\$ 0.44$ & $\$ 0.2$ \\
\hline Standard deviation & & $28.4 \%$ & - & $2.9 / 3$ & $6.8 \%$ & $\$ 4.2$ & $\$ 1.7$ \\
\hline Quebec & 159 & & & & & & \\
\hline Mean & & $37.4 \%$ & $100 / 58$ & $7.1 / 5.3$ & $2.8 \%$ & $\$ 0.5$ & $\$ 1.0$ \\
\hline Median & & $32.1 \%$ & - & $7 / 5$ & $0 \%$ & $\$ 0.3$ & $\$ 0.15$ \\
\hline Standard deviation & & $30.6 \%$ & - & $3.4 / 3$ & $8.1 \%$ & $\$ 0.8$ & $\$ 2.5$ \\
\hline $\begin{array}{l}\text { New Brunswick, } \\
\text { Nova Scotia and } \\
\text { Newfoundland \& } \\
\text { Labrador }\end{array}$ & 28 & & & & & & \\
\hline Mean & & $30.5 \%$ & $15 / 7$ & $6.6 / 4.9$ & $1.3 \%$ & $\$ 1.2$ & $\$ 1.3$ \\
\hline Median & & $20.3 \%$ & - & $6 / 4$ & $0 \%$ & $\$ 0.1$ & $\$ 0.8$ \\
\hline Standard deviation & & $32.1 \%$ & - & $3.7 / 3.1$ & $3.1 \%$ & $\$ 2.4$ & $\$ 1.2$ \\
\hline All TSX & 1,452 & & & & & & \\
\hline Mean & & $23.4 \%$ & $600 / 288$ & $6.1 / 4.3$ & $3.4 \%$ & $\$ 0.3$ & $\$ 1.2$ \\
\hline Median & & $13.0 \%$ & - & $6 / 4$ & $0 \%$ & $\$ 0.13$ & $\$ 0.3$ \\
\hline Standard deviation & & $7.4 \%$ & - & $0.1 / 0.2$ & $2.4 \%$ & $\$ 0.3$ & $\$ 0.6$ \\
\hline
\end{tabular}

Blockholders are shareholders who control 10\% or more of firm's votes. Cumulative blockholder votes per firm are estimated by aggregating the votes of all blockholders. The number of firms with $20 \%$ $(50 \%)$ ownership stakes is obtained by counting the firms in which blockholders control at least $20 \%$ (50\%) of total votes. CEO cash pay is estimated by aggregating base salaries and cash bonuses. CEO performance pay is estimated by aggregating the value of stock option and restricted shares granted as reported in the management proxy circular.

The differences between Eastern and Western Canada are already visible. In Alberta, the resource-driven boom has produced strong economic growth, attracted entrepreneurs, labor, and augmented economic prosperity. Here, publicly listed corporations are more dynamic, tend to grow faster, and appear more widely held. Of 281 firms, only 92, or about one third have cumulative ownership stakes of $20 \%$ or more of total votes (Table 1, Panel A). 
Table 1. Panel B: Average market capitalization of domestic firms by province.

\begin{tabular}{|l|l|l|l|l|}
\hline Province & $\begin{array}{l}\text { Number } \\
\text { of firms }\end{array}$ & $\begin{array}{l}\text { Average market } \\
\text { capitalization } \\
\text { per firm ('000) }\end{array}$ & $\begin{array}{l}\text { Total average } \\
\text { market } \\
\text { capitalization } \\
\mathbf{( ' 0 0 0 )}\end{array}$ & $\begin{array}{l}\text { Percentage } \\
\text { of total }\end{array}$ \\
\hline $\begin{array}{l}\text { British } \\
\text { Columbia }\end{array}$ & 191 & $\$ 756.1$ & $\$ 144,415.0$ & $6.72 \%$ \\
\hline $\begin{array}{l}\text { Alberta } \\
\text { Manitoba and } \\
\text { Saskatchewan }\end{array}$ & 27 & $\$ 2,142.6$ & $\$ 602,070.6$ & $28.02 \%$ \\
\hline $\begin{array}{l}\text { Ontario } \\
\text { Quebec }\end{array}$ & 692 & $\$ 1,506.9$ & $\$ 103,577.4$ & $4.82 \%$ \\
\hline $\begin{array}{l}\text { New Brunswick, } \\
\text { Nova Scotia and } \\
\text { Newfoundland } \\
\text { \& Labrador }\end{array}$ & 28 & $\$ 1,491.1$ & $\$ 1,042,744.8$ & $48.54 \%$ \\
\hline $\begin{array}{l}\text { Total domestic } \\
\text { listings }\end{array}$ & $\mathbf{1 , 3 7 8}$ & $\$ 658.7$ & $\$ 237,084.9$ & $11.04 \%$ \\
\hline
\end{tabular}

Average market capitalization is estimated by talking the average of the previous 52 weeks low and high stock prices, multiplied by the number of outstanding shares.

The average cumulative blockholding per firm is at $17 \%$, while the median one is at $10 \%$. Ontario and British Columbia show about $40 \%$ of listed firms having cumulative ownership stakes of $20 \%$ or more. The average cumulative blockholding stake is $21 \%$ for Ontario and $23 \%$ for British Columbia. The median Ontario- and British Columbia-based company has only one blockholder. Arguably, firms headquartered in Alberta, Ontario and British Columbia are among the more widelyheld corporations in Canada. Of 27 listed firms from Manitoba and Saskatchewan, 12 show cumulative ownership stakes at or above the $20 \%$ threshold. The average cumulative ownership stake is at $31 \%$, while the median is at $12 \%$.

At the other end of the spectrum, Quebec and Atlantic Canada boast the most concentrated ownership patterns in Canada. It is hard, however to draw meaningful conclusions for smaller provinces, such as New Brunswick, where the economy is dominated by the Irving group of companies that, in Diane Francis' words "...still run the province as if it is their own fiefdom (p 366)," yet remain privately held. As such, available data on publicly listed firms tends to understate the extent of ownership concentration that underpins the economy of Atlantic Canada.

Quebec is also home to firms with high ownership concentration. More than $60 \%$ of publicly listed Quebec corporations have cumulative ownership stakes of $20 \%$ or larger. The average firm has a cumulative ownership stake of almost $38 \%$, while the median is at $32 \%$. Both figures are the highest among all Canadian provinces. 
Executive shareholding is moderately low across the board. It averages just over $3 \%$ for the entire sample (the median is equal to zero). Among provinces, only Alberta stands out with a $10 \%$ executive control average (again, a median equal to zero).

The analysis of CEO compensation numbers reveals a mixed picture. It is clear, however, that there is great variability in the size and composition of pay across provinces and within individual provinces. Average values deviate from medians significantly: pay scales are markedly skewed. Albertan firms stand out as having the highest ratio of CEO performance pay to cash compensation, almost 2:1 (according to median values). British Columbia, Manitoba and Saskatchewan corporations also show a relatively high proportion of performance pay. Ontario and Quebec firms, however, show lower levels of CEO performance pay relative to cash pay, about 1:2 (according to median values). Overall, Ontario firms have the highest level of total CEO compensation.

Tests for the significance of means and paired two-sample tests are presented in Table 2 (for cumulative ownership stakes). All the t-statistics for the larger provinces and pairs of larger provinces are significant at the 5\% level. Smaller provinces have been grouped into two regions to overcome the scarcity of the observations: Manitoba and Saskatchewan form one region, and New Brunswick, Nova Scotia and NewFoundland \& Labrador (NFL) form the second one. In spite of this, the number of observations remains small for Atlantic Canada, Manitoba and Saskatchewan (and the tests for the significance of means appear marginally significant at the 10\%-11\% level). One can only be certain that there are statistically significant ownership differences among Ontario, Quebec, and Alberta on the one hand, and among British Columbia, Alberta, and Quebec on the other hand. Ontario and British Columbia appear to have similar ownership concentration, as statistical tests fail to reject the null hypothesis. 
Table 2.

\begin{tabular}{|c|c|c|c|c|c|c|}
\hline & $\begin{array}{l}\text { British } \\
\text { Columbia }\end{array}$ & Alberta & $\begin{array}{l}\text { Manitoba and } \\
\text { Saskatchewan }\end{array}$ & Ontario & Quebec & $\begin{array}{l}\text { New Brunswick, } \\
\text { Nova Scotia and } \\
\text { NewFoundland } \\
\text { \& Labrador }\end{array}$ \\
\hline $\begin{array}{l}\text { British } \\
\text { Columbia }\end{array}$ & $12.01 *$ & $-2.15^{*}$ & -1.16 & 0.76 & $-4.56^{*}$ & -1.3 \\
\hline Alberta & & $11.88^{*}$ & $-2.13^{*}$ & $-1.93 *$ & $-6.79 *$ & $-2.12^{*}$ \\
\hline $\begin{array}{l}\text { Manitoba } \\
\text { and } \\
\text { Saskatchewan }\end{array}$ & & & 5.49 & 1.6 & -1.3 & -0.2 \\
\hline Ontario & & & & $20.04 *$ & -5.96 & -1.6 \\
\hline Quebec & & & & & $15.46^{*}$ & -0.88 \\
\hline $\begin{array}{l}\text { New } \\
\text { Brunswick, } \\
\text { Nova Scotia } \\
\text { and New } \\
\text { Foundland }\end{array}$ & & & & & & 5.03 \\
\hline
\end{tabular}

Because tests involving smaller provinces yield statistics that are insignificant or only marginally significant, an alternative grouping is used; fortunately, this approach produces clear cut results. This time, Canadian firms have been divided into two groups: British Columbia, Alberta, Saskatchewan, Manitoba and Ontario in one group (Central and Western Canada), and Quebec, New Brunswick, Nova Scotia, and NFL in the second (Eastern Canada). The t-test for paired sample means is statistically significant (at the 5\% level), indicating a considerable difference between the two groups: Eastern Canada has unquestionably higher levels of corporate ownership concentration than the rest of the country.

\section{Ownership and Size}

The ranking of TSX listed firms according to market capitalization is presented in Table 3. The top 50 TSX corporations (a mere 4\% of the total number of listed firms) account for almost $60 \%$, and the top 500 companies account for over $83 \%$ of the total domestic market capitalization of the Toronto Stock Exchange (Table 3, Panel B). Clearly, the fortunes of the Canadian stock market ride on the wings of a few large corporations; as the luck of these firms change so does the welfare of Canadian investors. There is no secret that the Canadian economy and its stock market are dominated by a handful of large corporations. These numbers give a true measure of the scope and extent of this tremendous economic concentration. 
Table 3. Panel A: Ranking of TSX listed firms according to market capitalization.

\begin{tabular}{|c|c|c|c|c|c|c|}
\hline & $\begin{array}{l}\text { Cumulative } \\
\text { blockholder votes } \\
\text { per firm \% }\end{array}$ & $\begin{array}{l}\text { Number of firms } \\
\text { with } 20 \% / 50 \% \\
\text { cumulative } \\
\text { ownership stakes }\end{array}$ & $\begin{array}{l}\text { Directors /of } \\
\text { which } \\
\text { independent }\end{array}$ & $\begin{array}{l}\text { Executive } \\
\text { share holding } \\
\%\end{array}$ & $\begin{array}{l}\text { CEO cash pay } \\
\text { (\$mil) }\end{array}$ & $\begin{array}{l}\text { CEO } \\
\text { performance } \\
\text { pay (\$mil) }\end{array}$ \\
\hline \multicolumn{7}{|c|}{$\begin{array}{l}\text { Largest } 50 \text { (\$ mil) } \\
\$ 137,197.9-\$ 8,688.2\end{array}$} \\
\hline Mean & $19.6 \%$ & $16 / 12$ & $10.5 / 9.5$ & $0.2 \%$ & $\$ 0.8$ & $\$ 3.9$ \\
\hline Median & $0 \%$ & - & $12 / 10$ & $0 \%$ & $\$ 0.7$ & $\$ 3.4$ \\
\hline Standard deviation & $27.8 \%$ & - & $4.8 / 3.6$ & $0.9 \%$ & $\$ 0.7$ & $\$ 3.7$ \\
\hline \multicolumn{7}{|l|}{$\begin{array}{l}\text { Largest } 100 \text { (\$ mil) } \\
\$ 137,197.9-\$ 2,705.1\end{array}$} \\
\hline Mean & $18.2 \%$ & $30 / 19$ & $9.6 / 8.4$ & $0.5 \%$ & $\$ 0.5$ & $\$ 3.1$ \\
\hline Median & $0 \%$ & - & $10 / 8$ & $0 \%$ & $\$ 0.7$ & $\$ 1.6$ \\
\hline Standard deviation & $25.6 \%$ & - & $4.3 / 3.3$ & $3.5 \%$ & $\$ 0.3$ & $\$ 4.1$ \\
\hline \multicolumn{7}{|l|}{$\begin{array}{l}\text { Largest } 500 \text { (\$ mil) } \\
\$ 137,197.9-\$ 266.4\end{array}$} \\
\hline Mean & $22.5 \%$ & $197 / 92$ & $7.2 / 5.6$ & $1.44 \%$ & $\$ 0.7$ & $\$ 1.5$ \\
\hline Median & $11.7 \%$ & - & $7 / 5$ & $0 \%$ & $\$ 0.3$ & $\$ 0.6$ \\
\hline Standard deviation & $27.9 \%$ & - & $3.4 / 3$ & $5 \%$ & $\$ 1.6$ & $\$ 2.5$ \\
\hline \multicolumn{7}{|l|}{ All 1,452 TSX firms } \\
\hline Mean & $23.4 \%$ & $600 / 288$ & $6.1 / 4.3$ & $3.4 \%$ & $\$ 0.3$ & $\$ 1.2$ \\
\hline Median & $13.0 \%$ & - & $6 / 4$ & $0 \%$ & $\$ 0.13$ & $\$ 0.3$ \\
\hline Standard deviation & $7.4 \%$ & - & $0.1 / 0.2$ & $2.4 \%$ & $\$ 0.3$ & $\$ 0.6$ \\
\hline
\end{tabular}

Blockholders are shareholders who control 10\% or more of firm's votes. Cumulative blockholder votes per firm are estimated by aggregating the votes of all blockholders. The number of frms with $20 \%$ (50\%) ownership stakes is obtained by counting the firms in which blockholders control at least $20 \%$ (50\%) of total votes. CEO cash pay is estimated by aggregating base salaries and cash bonuses. CEO performance pay is estimated by aggregating the value of stock option and restricted shares granted as reported in the management proxy circular.

Table 3. Panel B: Average market capitalization of the largest firms.

\begin{tabular}{|l|l|l|l|}
\hline $\begin{array}{l}\text { Largest firms by market } \\
\text { capitalization }\end{array}$ & Number of firms & $\begin{array}{l}\text { Average market capitalization } \\
\text { per firm ('000) }\end{array}$ & $\begin{array}{l}\text { Total average market } \\
\text { capitalization ('000) }\end{array}$ \\
\hline Top $\mathbf{5 0}$ & 50 & $\$ 25,465.6$ & $\$ 1,273,280$ \\
\hline total
\end{tabular}

Average market capitalization is estimated by talking the average of the previous 52 weeks low and high stock prices, multiplied by the number of outstanding shares.

The ownership of larger firms seems somewhat less concentrated then the average. Cumulative ownership stakes are slightly lower than the TSX average (Table 1, Panel A). Top 50 and 100 TSX firms have median cumulative blockholder stakes of zero. The frequency of cumulative ownership stakes at the $20 \%$ cut-off is around $30 \%$ for the top 50 and 100 TSX firms, increasing to almost $40 \%$ for the top 500 .

Board size and CEO compensation tend to increase with size. One would expect that larger firms have larger boards and pay their CEO more. Executive ownership is very small, yet it appears to be edging up slightly as smaller firms are included, and the ranking is gradually expanded. 
Table 4. Panel A: Ranking of TSX listed firms according to assets size.

\begin{tabular}{|c|c|c|c|c|c|c|}
\hline & $\begin{array}{l}\text { Cumulative } \\
\text { blockholder votes } \\
\text { per firm \% }\end{array}$ & $\begin{array}{l}\text { Number of } \\
\text { firms with } \\
20 \% / 50 \% \\
\text { cumulative } \\
\text { ownership } \\
\text { stakes }\end{array}$ & $\begin{array}{l}\text { Directors } \\
\text { /of which } \\
\text { independent }\end{array}$ & $\begin{array}{l}\text { Executive } \\
\text { share } \\
\text { holding } \\
\%\end{array}$ & $\begin{array}{l}\text { CEO cash pay } \\
(\$ \text { mil) }\end{array}$ & $\begin{array}{l}\text { CEO } \\
\text { performance } \\
\text { pay (\$ mil) }\end{array}$ \\
\hline \multicolumn{7}{|c|}{$\begin{array}{l}\text { Largest } 50(\$ \mathrm{mil}) \\
\$ 536,780-\$ 107,202.2\end{array}$} \\
\hline Mean & $10.3 \%$ & $15 / 2$ & $5.8 / 4.4$ & $0.9 \%$ & $\$ 6.6$ & $\$ 3.1$ \\
\hline Median & $0 \%$ & - & $4 / 2$ & $0 \%$ & $\$ 8.3$ & $\$ 0.6$ \\
\hline Standard deviation & $17 \%$ & - & $4.8 / 5.18$ & $2.6 \%$ & $\$ 3.9$ & $\$ 4$ \\
\hline \multicolumn{7}{|l|}{$\begin{array}{l}\text { Largest } 100(\$ \mathrm{mil}) \\
\$ 536,780-\$ 32,098.1\end{array}$} \\
\hline Mean & $11.6 \%$ & $33 / 6$ & $5.5 / 4$ & $1.2 \%$ & $\$ 6.4$ & $\$ 1.8$ \\
\hline Median & $0 \%$ & - & $5 / 3$ & $0 \%$ & $\$ 1.9$ & $\$ 0.5$ \\
\hline Standard deviation & $18.1 \%$ & - & $4.3 / 4.5$ & $2.6 \%$ & $\$ 4.7$ & $\$ 3.1$ \\
\hline \multicolumn{7}{|l|}{$\begin{array}{l}\text { Largest } 500 \text { (\$ mil) } \\
\$ 536,780-\$ 393.1\end{array}$} \\
\hline Mean & $21 \%$ & $194 / 84$ & $6.9 / 5.3$ & $1.4 \%$ & $\$ 2.3$ & $\$ 1.6$ \\
\hline Median & $11.5 \%$ & - & $7 / 5$ & $0 \%$ & $\$ 0.8$ & $\$ 0.5$ \\
\hline Standard deviation & $27.4 \%$ & - & $3.8 / 3.6$ & $4.9 \%$ & $\$ 3.6$ & $\$ 2.7$ \\
\hline \multicolumn{7}{|l|}{ All 1,452 TSX firms } \\
\hline Mean & $23.4 \%$ & $600 / 288$ & $6.1 / 4.3$ & $3.4 \%$ & $\$ 0.3$ & $\$ 1.2$ \\
\hline Median & $13.0 \%$ & - & $6 / 4$ & $0 \%$ & $\$ 0.13$ & $\$ 0.3$ \\
\hline Standard deviation & $7.4 \%$ & - & $0.1 / 0.2$ & $2.4 \%$ & $\$ 0$. & \\
\hline
\end{tabular}

The ranking of TSX firms according to asset size is presented in Table 4. The frequency of cumulative blockholding stakes $20 \%$ or higher equals about $1 / 3$ of the firms for the top 50 and 100 , and it edges closer to $40 \%$ for the top 500 .

Table 4. Panel B: Average market capitalization of the largest firms.

\begin{tabular}{|c|c|c|c|c|}
\hline $\begin{array}{l}\text { Largest firms by total } \\
\text { assets }\end{array}$ & Number of firms & $\begin{array}{l}\text { Average market capitalization per } \\
\text { firm ('000) }\end{array}$ & $\begin{array}{l}\text { Total average market } \\
\text { capitalization ('000) }\end{array}$ & $\begin{array}{l}\text { Percentage of } \\
\text { total }\end{array}$ \\
\hline Top 50 & 50 & $\$ 9,521.3$ & $\$ 476,065.0$ & $21.68 \%$ \\
\hline Top 100 & 100 & $\$ 6,566.4$ & $\$ 656,640.0$ & $29.90 \%$ \\
\hline Top 500 & 500 & $\$ 3,584.4$ & $\$ 1.792,200.0$ & $81.62 \%$ \\
\hline All TSX & 1,452 & & $\$ 2,195,859.6$ & $100 \%$ \\
\hline
\end{tabular}

Average market capitalization is estimated by talking the average of the previous 52 weeks low and high stock prices, multiplied by the number of outstanding shares.

Board size is similar across all rankings, decreasing in size; the CEOs of the largest TSX firms as measured by assets command by far the most generous pay. The average annual CEO pay for the top 50 firms is close to $\$ 10$ million. Remarkably, the structure of the compensation package is quite different from that of the entire TSX sample. For the top 500 firms, a large proportion is paid in cash, i.e. $59 \%$, while only $41 \%$ is made of options, restricted shares and other forms of performance pay.

The top 50 firms by market capitalization largely overlap with the top 50 firms by asset size. In other words, the Canadian equity market is dominated by a handful of firms that account for a staggering fraction of total market capitalization, and control an overwhelming proportion of productive assets (Table 5). 
Table 5. A side by side comparison of the top largest 50 TSX firms, ranked by assets and market capitalization.

\begin{tabular}{|c|c|c|}
\hline & $\begin{array}{l}\text { Top largest } 50 \text { TSX firms by } \\
\text { assets (TOP50A) }\end{array}$ & $\begin{array}{l}\text { Top largest } 50 \text { TSX firms by } \\
\text { market capitalization } \\
\text { (TOP50MC) }\end{array}$ \\
\hline Average assets ('000) & $\$ 240,052,550.5$ & $\$ 70,314,858$ \\
\hline Median assets ('000) & $\$ 209,933,143$ & $\$ 17,774,950$ \\
\hline Average market capitalization ('000) & $\$ 9,521,254$ & $\$ 25,465,595$ \\
\hline Average market capitalization ('000) & $\$ 253,985$ & $\$ 19,884,046$ \\
\hline Average annual revenues ('000) & $\$ 29,462,503$ & $\$ 9,457,344$ \\
\hline Median annual revenues ('000) & $\$ 13,104,000$ & $\$ 7,623,447$ \\
\hline Total debt ratio & $50.6 \%$ & $66.3 \%$ \\
\hline Long-term debt ratio & $29.3 \%$ & $38.1 \%$ \\
\hline Average ROA & $-0.23 \%$ & $5.77 \%$ \\
\hline Median ROA & $0.94 \%$ & $4.67 \%$ \\
\hline Average market-to-book ratio & 1.48 & 254.3 \\
\hline Median market-to-book ratio & 1.76 & 2.95 \\
\hline Average number of employees & 11,639 & 24,244 \\
\hline Median number of employees & 330 & 7,103 \\
\hline Average sales per employee ('000) & $\$ 1,114,506$ & $\$ 2,704$ \\
\hline Median sales per employee ('000) & $\$ 48,316$ & $\$ 392$ \\
\hline Average number of blockholders per firm & 0.46 & 0.64 \\
\hline Median number of blockholders per firm & 0 & 0 \\
\hline Average votes per share & 1 & 1.07 \\
\hline Firms with $20 \%$ cumulative ownership stakes & 15 & 30 \\
\hline Firms with $50 \%$ cumulative ownership stakes & 2 & 19 \\
\hline Average board size & 5.9 & 10.49 \\
\hline Median board size & 4 & 12 \\
\hline Firms with directors controlling al least $20 \%$ of votes & 7 & 3 \\
\hline Firms with directors controlling al least $50 \%$ of votes & 0 & 2 \\
\hline Average total CEO compensation ('000) & $\$ 9,730$ & $\$ 4,713$ \\
\hline Median total CEO compensation ('000) & $\$ 9,170$ & $\$ 3,772$ \\
\hline Average performance CEO compensation ('000) & $\$ 3,096$ & $\$ 3,980$ \\
\hline Median performance CEO compensation ('000) & $\$ 608$ & $\$ 3,349$ \\
\hline \multicolumn{3}{|c|}{ 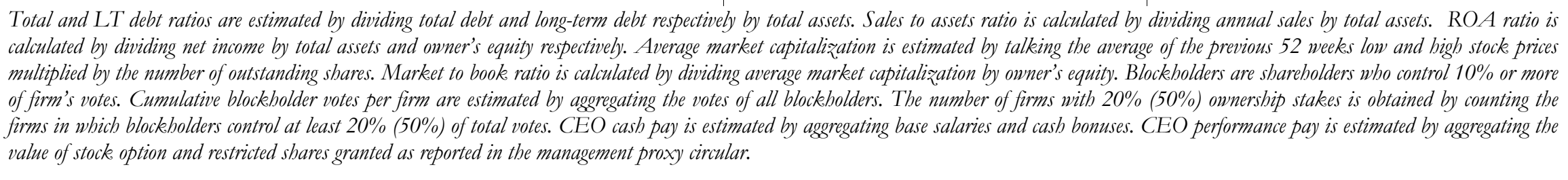 } \\
\hline
\end{tabular}

There is a dramatic difference in the level and structure of CEO pay between the two rankings. For example, the top 50 firms by assets (TOP50A) pay between two and three times more in managerial compensation than the top 50 firms by market capitalization (TOP50MC). At the same time, the proportion of performance pay in TOP50A is much lower. The average CEO performance pay represents about $1 / 3$ of total pay, while the median CEO performance pay represents a mere $7 \%$ of total pay. By contrast, the proportion of performance pay in TOP50MC is much higher. The average CEO performance pay represents close to $85 \%$ of total pay, while the median CEO performance pay represents almost $88 \%$ of total pay.

\section{Cluster Analysis}

In order to gain further insight into the grouping of the data that might not be otherwise apparent, an exploratory two-step cluster analysis is employed. This methodology has the advantage of making use of both continuous and dichotomous variables. The maximum number of clusters has been set equal to six and the number of variables has been set equal to four: total assets (a measure of firm size), the province in which the corporation is headquartered, and two binary measures of ownership concentration (cumulative ownership stakes at the $20 \%$ and $50 \%$ cut-off). These limits have been set for obvious reasons, as too much complexity would have made the interpretation of the results difficult.

The results are presented in Table 6. The clustering procedure generates one group consisting of Very Large firms (over $\$ 80$ billion in assets on average), two groups of relatively medium-sized firms, i.e. Medium 1 and Medium 2 (around $\$ 6$ billion in assets on average), two groups of relatively smaller firms, Smaller1 and Smaller2 (around \$4 billion in assets on average), and one group of Very Small firms (around \$2 billion in assets on average). 
Table 6 .

\begin{tabular}{|c|c|c|c|c|c|c|c|c|}
\hline & & $\begin{array}{l}\text { Smaller1: } \\
\text { Just under } \$ 4 \\
\text { b }\end{array}$ & $\begin{array}{l}\text { Smaller2: } \\
\text { Just over } \$ 4 \text { b }\end{array}$ & $\begin{array}{l}\text { Very large: } \\
\text { Over } \$ 80 \text { b }\end{array}$ & $\begin{array}{l}\text { Medium1: } \\
\text { Just over } \$ 6 \text { b }\end{array}$ & $\begin{array}{l}\text { Medium2: } \\
\text { Over } \$ 6 \text { b }\end{array}$ & $\begin{array}{l}\text { Very Small: Just } \\
\text { over } \$ 2 \mathrm{~b}\end{array}$ & Combined \\
\hline Freq. & & 401 & 277 & 130 & 174 & 219 & 251 & 1,452 \\
\hline$\% 1$ & & $27.6 \%$ & $19.1 \%$ & $9.0 \%$ & $12.0 \%$ & $15.1 \%$ & $17.3 \%$ & $100.0 \%$ \\
\hline \multirow{2}{*}{$\begin{array}{l}\text { Total } \\
\text { assets } \\
\left({ }^{\circ} 000\right)\end{array}$} & Mean & $\$ 3,786,666.00$ & $\$ 4,404,183.59$ & $\$ 83,993,533.65$ & $\$ 6,192,697.08$ & $\$ 6,399,152.64$ & $\$ 2,160,430.12$ & $\$ 11,486,765.13$ \\
\hline & $\begin{array}{l}\text { Std. } \\
\text { Deviation }\end{array}$ & $\$ 14,392,568.218$ & $\$ 16,664,873.007$ & $\$ 141,160,209.773$ & $\$ 18,763,380.380$ & $\$ 19,820,460.666$ & $\$ 8,986,608.901$ & $\$ 50,156,309.072$ \\
\hline $\mathrm{AB}$ & Freq. & 0 & 276 & 5 & 0 & 0 & 0 & 281 \\
\hline $\mathrm{BC}$ & Freq. & 0 & 0 & 0 & 114 & 44 & 32 & 191 \\
\hline Maritimes & Freq. & 0 & 0 & 21 & 0 & 0 & 7 & 28 \\
\hline MB & Freq. & 0 & 0 & 10 & 0 & 0 & 10 & 20 \\
\hline $\mathrm{ON}$ & Freq. & 401 & 0 & 26 & 0 & 132 & 133 & 692 \\
\hline Other & Freq. & 0 & 0 & 57 & 0 & 0 & 11 & 68 \\
\hline QC & Freq. & 0 & 0 & 4 & 57 & 41 & 57 & 159 \\
\hline SK & Freq. & 0 & 0 & 7 & 0 & 0 & 0 & 7 \\
\hline \multicolumn{9}{|c|}{$20 \%$ ownership stake or larger } \\
\hline 0 & Freq. & 401 & 187 & 90 & 174 & 0 & 0 & 852 \\
\hline 1 & Freq. & 0 & 90 & 40 & 0 & 219 & 251 & 600 \\
\hline \multicolumn{9}{|c|}{$50 \%$ ownership stake or larger } \\
\hline 0 & Freq. & 401 & 241 & 129 & 174 & 219 & 0 & 1,164 \\
\hline 1 & Freq. & 0 & 36 & 1 & 0 & 0 & 251 & 288 \\
\hline
\end{tabular}

Exploratory two-step cluster analysis. Ownership stakes of 20\%(50\%) or larger represent binary variables that take the value of one if the combined ownership stake of all large shareholders equals or exceeds $20 \%(50 \%)$.

The distribution of ownership stakes into these six groups largely conforms to earlier findings. The overwhelming proportion of firms (over 90\%) with ownership stakes at the $20 \%$ cut-off belongs to the medium, smaller, and very small clusters. This result is not surprising. Upon closer inspection, however, it appears that firms in the medium and smaller clusters evolve in two parallel worlds. One the one hand we have widely-held firms accounting for the entire Smaller1 and Medium 1 clusters. On the other hand we have tightly controlled firms making up a good portion (90 of 277 firms) of the Smaller2 cluster, and accounting for the entire Medium2 cluster. Remarkably, the Very Small cluster consists entirely of firms showing ownership stakes at, or above the $50 \%$ cut-off.

However, only 40 of the 130 Very Large firms, show ownership stakes at the $20 \%$ cut-off. This figure appears smaller than that reported by La Porta et al. (1999). When the 50\% cut-off is used, only one of 130 Very Large firms remains closely controlled; virtually all firms with large blockholding stakes appear to belong to the Smaller1 and 2 and Very Small clusters.

The clustering by province also produces results consistent with earlier findings, although there are some additional insights to report. First, Atlantic Canada, Saskatchewan, and foreign listings (labeled as "Other") are associated with Very Large firms. This is normal for foreign listings: in order to be cross-listed on a foreign exchange, these firms must have achieved a considerable size before they can consider issuing capital globally. In the case of the smaller Canadian provinces - Saskatchewan, New Brunswick, Nova Scotia, and NFL - this evidence suggests that in spite of their less diversified economies, there could be advantages that can be readily achieved through economies of scale. The most balanced distribution is associated with Ontario, where all groups are well represented. Given the size and complexity of its economy, this is hardly surprising. Alberta has an overwhelming majority of firms in the Smaller2 category. Quebec and British Columbia see virtually all of their corporations in the Medium1, Medium2 and Very Small groups (excepting four firms that are very large). This last result is very telling, given the observed ownership patterns in the two provinces. Quebec boasts a more concentrated corporate ownership than British Columbia, and this result cannot be attributed only to the smaller size of its corporations. Since firm size distribution is very similar in both provinces, something else has to account for differences in corporate ownership patterns.

\section{A Brief Note on CEO Pay}

Although it is not the purpose of this paper to investigate exhaustively other mechanisms of internal corporate governance, one is naturally enticed to report and comment on a particular result that stands out in the area of executive compensation.

We note that Canada too has seen a steady rising in the importance of performance pay. Jensen and Murphy (1990) launched a call to arms of sorts when documenting low levels of performance-pay sensitivity in the 1980s. Ever since, the mantra of executive pay-performance has become a basic staple of the corporate governance discourse. Today, stock options and/or restricted shares make up for the majority of the executive compensation package. The CEO of the typical TSX firm expects to receive about $70 \%$ of his pay in the form of performance incentives.

Another result reported here shows that firms with very large assets have high levels of total executive compensation, yet a relatively low performance-pay component; this finding, however, fits into the empirical literature on CEO compensation [Murphy (1995)]. We also find that firms with higher level of ownership concentration tend to pay less in stock options and restricted shares. This is particularly true for firms with a significant control wedge (multiple-class shares, with a high average number of votes per share). In a similar vein, Mehran (1995) shows firms in which a higher percentage of the shares are held by insiders and/or large shareholders use less equity-based compensation. These findings warrant a brief comment.

There is no decisive ex-ante argument that would settle the issue of what to expect in terms of CEO compensation structure in the case of closely controlled firms. Following Jensen and Meckling (1976), Fama (1980), Demsetz (1983), Demsetz and Lehn (1985), and Jensen (1993), the irreducible agency problem that pervade the relationship between managers and shareholders can be appeased by large shareholders because they internalize a significant portion of the costs associated with managerial discretion. Large shareholders have both the power and the incentive to monitor managers and discipline those who stray [Holderness and Sheehran (1988), Shleifer and Vishny (1986 and 1997)]. These theoretical considerations, however, do little in terms of predicting the actual structure of a compensation package in the presence of large shareholders. It can be easily argued that blockholders are in a position to design better compensation packages in which pay is more closely related to firm performance. At the same time one could contend that since CEOs are subject to more effective scrutiny 
and monitoring, there is really little need for a large pay-performance component. Blockholders take a more long-term approach to firm performance, value internal benefits of control, and rely on more diversified criteria for evaluating performance [Dechow and Sloan (1991)]. Options and restricted stock could very well be used only as a substitute for close monitoring by blockholders.

In the end, however, one feels that the results presented here fit very well into the theory of managerial rent extraction. It is noted that the dramatic increase in CEO compensation taking place over the last two decades has relied on the unrelenting growth in options and shares awarded to managers. [Bebchuk and Grinstein (2005)]. Riding on the wings of a bubbling stock market, especially during the 1990s, the CEOs of the publicly owned Canadian corporations have been able to extract increasingly larger rents in the form of options and common stock. As such, the presence of a large compensation package heavily weighted towards the pay-performance component does not necessarily entail more tightly aligned economic incentives; it rather suggests managerial opportunism emboldened by the market expansion. [Yermack (1995 and 1997)]. Options overcome to some extent the "outrage constraint" associated with large cash payments, and create the appearance that compensation is well deserved, especially during a bull market. Managerial power dictates the magnitude of the rent extraction [Bebchuk et al (2002)]. In widely-held firms, with atomized and dispersed ownership, there is a greater chance to observe higher CEO pay, because dispersed ownership is unable to overcome the problem of collective action. Here, CEOs wield more power.

Large shareholders, however, have the power and motivation to limit the rents extracted by managers. As argued above, performance pay might be thus viewed as redundant and used to a lesser extent.

\section{A Recapitulation}

It is perhaps useful to summarize the salient empirical findings of this paper. For a better perspective, these findings are compared and contrasted in Table 7 to those reported earlier by La Porta (1998), Morck et al. (2005), Morck and Yeung (2006), Attig and Gadhoum (2003), Bozec et al (2006), and Bozec and Laurin (2006).

Table 7

\begin{tabular}{|c|c|c|c|c|c|}
\hline & La Porta et al. (1999) & $\begin{array}{l}\text { Morck et al. (2005), } \\
\text { Morck and Yeung } \\
\text { (2006) }\end{array}$ & Gadhoum (2006) & $\begin{array}{l}\text { Bozec et al (2006), } \\
\text { Bozec and Laurin } \\
\text { (2006) }\end{array}$ & Current paper \\
\hline Sample size & $\begin{array}{l}\text { Top } 20 \text { largest Canadian firms } \\
\text { and } 10 \text { smaller firms with a } \\
\text { capitalization of at least } \$ 500 \\
\mathrm{~m} \text { at the end of } 1995\end{array}$ & $\begin{array}{l}\text { Various sample sizes, up } \\
\text { to } 500 \text { large Canadian } \\
\text { firms }\end{array}$ & $\begin{array}{l}\text { Between 1,121 and } \\
1,167 \text { Canadian firms } \\
\text { listed in Stock Guide in } \\
1996\end{array}$ & $\begin{array}{l}\text { The largest } 487 \text { publicly } \\
\text { held Canadian firms in } \\
1999\end{array}$ & $\begin{array}{l}1,452 \text { corporations listed } \\
\text { on the Toronto Stock } \\
\text { Exchange at the beginning } \\
\text { of } 2007\end{array}$ \\
\hline $\begin{array}{l}\text { Proportion of firms } \\
\text { with large shareholders } \\
(20 \% \text { of votes or } \\
\text { more })\end{array}$ & $\begin{array}{l}25 \%-30 \% \text { of firms controlled } \\
\text { by families } \\
\text { Most likely, the controlling } \\
\text { shareholder is alone }\end{array}$ & $30 \%$ of firms in 1996 & $\begin{array}{l}\text { About } 63 \% \text { of Canadian } \\
\text { corporations have } \\
\text { ownership stakes of } \\
20 \% \text { or larger } \\
\text { About } 82 \% \text { of Quebec } \\
\text { corporations have } \\
\text { ownership stakes of } \\
20 \% \text { or larger }\end{array}$ & $\begin{array}{l}\text { Quebec firms have more } \\
\text { concentrated ownership }\end{array}$ & $\begin{array}{l}\text { About } 41 \% \text { of firms across } \\
\text { the TSX have ownership } \\
\text { stakes of } 20 \% \text { or larger. } \\
\text { This figure ranges from } \\
62 \% \text { in Quebec to } 33 \% \text { in } \\
\text { Alberta } \\
\text { There is an average of } 0.93 \\
\text { and a median of } 1 \\
\text { blockholders per firm }\end{array}$ \\
\hline $\begin{array}{l}\text { Multiple-class shares } \\
\text { and pyramids }\end{array}$ & $\begin{array}{l}19.4 \% \text { of shares required to } \\
\text { own } 20 \% \text { of votes } \\
13 \% \text { of firms with ultimate } \\
\text { owners are controlled through } \\
\text { pyramids }\end{array}$ & $\begin{array}{l}\text { Up to } 50 \% \text { of the assets } \\
\text { of the top } 100 \text { firms } \\
\text { controlled trough } \\
\text { pyramids (citing Tian, } \\
\text { 2005) } \\
\text { A } 25 \% \text { ownership stakes } \\
\text { generates control over } \\
\text { about } 42 \% \text { of votes } \\
\text { (citing La Porta et al, } \\
\text { 1999) }\end{array}$ & $\begin{array}{l}\text { Quebec firms are more } \\
\text { likely to have multiple- } \\
\text { voting shares and } \\
\text { pyramid structures }\end{array}$ & $\begin{array}{l}37 \% \text { of closely held } \\
\text { firms have multiple- } \\
\text { voting shares } \\
\text { Quebec firms have more } \\
\text { concentrated ownership } \\
\text { and are more likely to } \\
\text { have multiple-voting } \\
\text { shares and pyramid } \\
\text { structures }\end{array}$ & $\begin{array}{l}\text { For the entire TSX sample, } \\
\text { the average share has } 1.13 \\
\text { votes, and the median } \\
\text { share has } 1 \text { vote. }\end{array}$ \\
\hline $\begin{array}{l}\text { Separation of } \\
\text { ownership from } \\
\text { control }\end{array}$ & $\begin{array}{l}\text { In every instance in which a } \\
\text { family controls a firm, it also } \\
\text { participate in its management }\end{array}$ & & & & $\begin{array}{l}\text { Directors control on } \\
\text { average } 25 \% \text { of votes in } \\
\text { the top } 500 \text { firms with the } \\
\text { most concentrated } \\
\text { ownership. }\end{array}$ \\
\hline CEO pay & & & & & $\begin{array}{l}\text { Performance pay } \\
\text { represents up to } 80 \% \text { of } \\
\text { total pay for the typical } \\
\text { TSX firm } \\
\text { Performance pay } \\
\text { represents less than } 50 \% \text { of } \\
\text { total pay for very large } \\
\text { firms (by assets), and firms } \\
\text { with high concentration of } \\
\text { ownership }\end{array}$ \\
\hline
\end{tabular}

Side by side comparison of findings from several recent studies on the ownership of public Canadian corporations. 
On average, corporate ownership in Canada is quite concentrated: about $40 \%$ of all firms have cumulative blockholding stakes of $20 \%$ or more. This is, however, less than the figures reported by Gadhoum (2006), but more than the figure reported by La Porta and al. (1999). The sample used by the latter, however is very small and consists of very large firms. When considering the ownership concentration of the top 50 largest firms in our sample, ownership concentration is not larger than that reported by La Porta et al. (1999).

The firms with the most concentrated ownership still account for a relatively important portion of total market capitalization, but this statement needs to be qualified. Up to one fourth of the total market capitalization of the TSX is accounted by 500 firms with the most concentrated ownership. While this figure is large it also suggests that the dominance of the closely controlled firm is not as dramatic as indicated by previous research.

Multiple-vote shares continue to play an important role in concentrating ownership. Firms such as Rogers Communications and Magna International show a significant control wedge, mainly due to the use of dual-class shares. In firms with a high degree of ownership concentration, there is a significant overlapping between ownership and management. One finds that $25 \%$ cumulative ownership stakes are in the hands of directors who are on the board of the top 500 firms with the most concentrated ownership.

It is fair to say that the Canadian market is dominated by about 500 firms or less that account for an overwhelming majority of assets and market capitalization. The concentration of economic power has two aspects: there are a handful of very large firms dominating the corporate landscape and another handful of firms closely controlled by a relatively small group of blockholders. Larger firms, however, show a relatively lower level of ownership concentration. As such, the dominance of the large firms does not necessarily engender the dominance of the closely controlled firm. The largest firms and the most closely controlled firms overlap to a certain degree, but the two groups are by no means identical.

Ownership patterns greatly differ between Eastern and Western Canada. The most concentrated ownership is found in Atlantic Canada and Quebec, and the most widely held firms are found in Alberta, Ontario, and British Columbia.

CEO compensation is dominated by performance pay with a few notable exceptions: the largest and the most concentrated ownership firms. Also, pay performance is lowest for the largest firms as measured by total assets.

\section{Discussion of results}

In this section we will present a brief discussion surrounding these results. The explanation of ownership patterns in Canada has been attempted before, yet most arguments have focused on law regime [La Porta (1998, and 1999), Bozec et al (2006)], private benefits of control, and taxation [Morck et al (2005)]. Here we will attempt to integrate various arguments into a picture that takes into account a broader range of historical, economic, political, and cultural factors. At times, our discussion will rely on speculative arguments. This is unavoidable, however, given the sheer complexity of the topic at hand. It is hard to envision how one should proceed to design empirical tests 
for all of the hypotheses discussed bellow. The non-linearity and multitude of feedback loops present in a social and economic system would raise serious challenges to any methodological design.

Why is economic power so concentrated in Canada? There is probably no single explanation. Bebchuk and Roe (1999) contend that the observed ownership patterns is path dependent. Its characteristics represent the emerging behavior of an extremely complex socio-economic system. Among the possible influences, one could cite demographic, geographic, historical and geopolitical patterns, cultural and religious heritage, taxation, and the duality of the legal system.

(i) Demographics. Canada is obviously a much smaller country than the United States. Although both countries roughly doubled their population between 1950 and 2008 to about 303 and 33 million inhabitants respectively (according to the US Census Bureau), Canada has represented all along only 10\% to $11 \%$ of the US population and economy ${ }^{4}$. As a country, it obviously lacked the demographic critical mass necessary for developing an internal market with enough depth and breadth to sustain US-style widely-held ownership. In a smaller economy one should expect to find fewer large enterprises, and those that are large are expected to dominate the economy. Hence, the "Canadian disease" is twofold: on the one hand, a handful of large corporations are in control of a large proportion of productive assets, and on the other hand, a handful of capitalists are in control of a large proportion of the publicly held firms.

Canada is in part a resource-driven economy. Natural resources account for a large portion of its gross domestic product and exports since the late $19^{\text {th }}$ century. Natural resources and commodities provide better scope for ownership concentration and entrenchment because they are associated with a special type of economic rents that rely on monopolistic ownership of critical assets that regulate and limit outsider access. [Rajan and Zingales (1998)]. The best way to realize economic rents is to ensure a tight control over critical assets and strictly regulate access [Tullock (1967)].

(ii) Law and Religion. Canada shares a similar legal system with other Englishspeaking countries. There is significant agreement concerning the role played by the legal system in generating protection for minority investors. La Porta et al (1998) finds that best investor rights are associated with common-law countries; not surprisingly, these countries also show the least concentrated corporate ownership. In reality, Canada is not, however, as homogeneous as other English-speaking countries. As noted already by Morck et al (2005), Attig et Gadhoum (2003), and Bozec et al. (2006), common-law co-exists with French civil law. A good portion of the Canadian gross domestic product is generated under a civil law regime. As such, it is understandable that Canada will also resemble, to a certain extent, countries like France, Italy, Brazil, Mexico, and Spain.

France, Italy, Brazil, Mexico, and Spain share not only the same legal system, but also the same religious heritage. They are all Catholic countries. By contrast, most English-speaking countries are protestant. Ever since Max Weber's The Protestant Ethic

4 According to the US Census Bureau, www.census.gov, accessed in May 2008 
and the Spirit of Capitalism, economists and sociologists have explained the Anglo-Saxon capitalist ethos in terms of religious heritage.

Fukuyama (1996) notes that a low trust environment - such as the one fostered by the Catholic culture - is more likely to produce economic organizations in which tight (family) control is viewed as a safeguard against the opportunism of outsiders. Banfield (1967) refers to this predicament as "amoral familism."

Stulz and Williamson (2003) vindicate both Weber and Fukuyama. They produce robust results showing that indeed, the protection of investor rights tends to be weaker in Catholic and stronger in Protestant countries.

With the exception of Ireland, Canada is the country with the largest representation of Catholics within the English-speaking world. The second-largest province, Quebec is Catholic, and so are many parts of Ontario, New Brunswick, Nova Scotia, Prince Edward Island, and NFL, colonized by the French and the Irish. By comparison to the United States, where Protestantism dominates and only $24 \%$ of all Christians are Catholics ${ }^{5}$, Canada continues to be dominated by Roman Catholicism, which represents the religious beliefs of almost $40 \%$ of the entire population ${ }^{6}$.

(iv) Taxation. Morck et al (2005) blame Canadian fiscal policy for the endurance of crony capitalism. Since the early 1920s the dividends received by Canadian corporations from other Canadian corporations remained tax exempt. This obviously provided greater opportunities for control pyramids and inter-locking shareholding to thrive. Later on, provincial and federal succession taxes became significant and apparently compelled many families to sell out. By the 1950s and early 1960s widely-held ownership in Canada was on the rise. According to Morck et all (2005), the big reversal occurred in the early 1970s when the Trudeau government greatly reduced succession taxes on large estates, and thus allowed corporate family empires to re-constitute and consolidate.

(v) Nationalism. The close relationship between politicians and capitalists has always been a landmark of Canadian culture. This tradition has been carried over into the present; as Diane Francis (2008) has noted, a majority of prime-ministers in recent decades can be directly or indirectly linked to the powerful economic elite.

Canadians had always been apprehensive of American Manifest Destiny [Warner (1960), Berton (1980)]. The overpowering presence of the US explains in part the identity crisis to which Canadians have always been prone, in the same way the English control over Quebec explains the perennial identity crisis of Quebecers. To the outside observer, Canadians often seem to define themselves in contrast to Americans [Adams (2003), Hurtig (2003), Thomas (2007)]. Canadian national identity has been forged in the process of rejecting the rogue populism of the Americans [Schwartz (1967), Berton (1982), Cohen (2007)]. A regrouping around local elites represented thus a logical step taken by a populace fearful of being engulfed by its much larger neighbor. Local elites provided the implicit promise of leadership and protection against the imperialist

\footnotetext{
5 Accoording to a 2004 Gallup poll

http://www.gallup.com/poll/14446/Update-Americans-Religion.aspx

6 According to Statistics Canada

http://www12.statcan.ca/english/census01/products/analytic/companion/rel/canada.cfm\#rc
} 
ambitions of the Americans in exchange for a continuation of their privileges and economic status.

A summary of our findings compared to those of several previous studies is presented in Table 7. This current paper documents levels of corporate ownership concentration that are lower than those found by Gadhoum (2006). We find that only about $40 \%$ of Canadian public firms have cumulative ownership stakes at the $20 \%$ cutoff, while previous studies have found this figure to equal $60 \%$. In the case of Quebec firms, our finding is about $60 \%$ versus $80 \%$ ten years ago. When examining the firms with the most concentrated ownership it becomes clearer that they do not account for an overwhelming proportion of the largest Canadian firms. Both the assets and the market capitalization of the most tightly controlled firms are rather modest by Canadian historical standards. Arguably, it were not for multiple-votes shares and pyramid structures, it is conceivable that their dominance would be even less than what we observe today (this vindicates the plea of Morck and Yeung (2006) for improved governance).

What are the factors driving the trend towards a more widely-held ownership? The economic pragmatism of the 1990s had important consequences [Rajan and Zingales (2004), Rodrik (2007)]. It nurtured the liberalization of trade and financial markets, and it favored economic immigrants over political refugees. A vibrant entrepreneurial culture combined with an expanding economy is more likely to succeed in dislodging the incumbent capitalist elite. This explanation is consistent with Mancur Olson's (1963) growth as a destabilizing force, and Rajan and Zingales (2003) interest group theory.

The North American Free Trade Association treaty (NAFTA) came in effect in 1994, and greatly enhanced the scope for trade and economic cooperation between Canada and the United States [Weintraub (2004), Hufbauer, Clyde, and Schott (2005), Curtis and Sydor (2006)]. It is possible that a bubbling economy, the re-assertion of a vibrant entrepreneurial culture, and the liberalization of trade and financial markets have combined together to increase the significance of widely-held firm in Canada.

\section{Concluding Remarks}

Canada is a complex country, with a relatively short yet eventful history, which has produced an intriguing story of political, social, and economic development. The federation, represented by a small population spread over a huge expanse of land, held out against all odds, and managed to find its path to prosperity, becoming one of the richest countries in the world. Canada's society is multicultural and its economy is an amazing mix of post-colonial and post-industrial characteristics. A vibrant social democracy thrives alongside the still strong remnants of a slowly vanishing economic plutocracy. 
From a historical perspective, a long-established and deeply-rooted tradition of economic elitism proved to be one of the more important factors shaping the Canadian economy. This tradition originated during the colonial period and carried over after the 1867 Confederation. The close proximity of the United States has produced a perennial uneasiness among Canadians fearful of being overcome by the rogue populism of their neighbor. It appears that Canadians sought comfort in the presence of a small yet powerful oligarchy cast in the role of gate-keeper of the Canadian national identity. This oligarchy showed a benevolent attitude toward generous social policies, which turned into a barrier to foreign competition. Successive changes in inheritance taxes, together with regulation allowing dual-class shares might have combined to keep corporate ownership concentration levels high, even during periods of economic liberalization. The importance of commodities has most likely compounded the propensity towards rent-seeking behavior.

Regional particularities caused by law regime and cultural traditions might have produced differentiation of ownership patterns among provincial lines. Ownership stakes are higher on average in Eastern Canada (including Quebec) than in the rest of the country. Ontario, Alberta, and British Columbia boast the most widely-held firms in the country.

Current evidence brought forward by this research shows that, nevertheless, the high levels of corporate ownership concentration prevalent during the 1980s and mid1990s have declined. The last fifteen years have seen an unprecedented global trend toward openness, financial liberalization, and economic pragmatism, and Canada has been a prime beneficiary of this trend. Outside of the United States, Canada offers yet another example of a real trend towards more widely-held ownership.

\section{References}

Adams M. (2003), Fire and Ice: The United States, Canada and the Myth of Converging Values, Penguin Books Canada

André P., Ben-Amar W., Saadi S. (2006), 'Corporate Governance and Acquiring Firm Shareholder Wealth: Evidence from High-Tech Acquisitions in Canada', working paper

Anderson R.C., Reeb D.M. (2003), 'Founding-Family Ownership and Firm Performance: Evidence from the S\&P 500', Journal of Finance, 58, 1301-29

Attig N., Gadhoum Y. (2003), 'Law Regime and Cultural Heritage as Determinants of Ownership: Demystifying the Puzzling Canadian Ownership Concentration', working paper

Attig N., Fischer K.P., Gadhoum Y. (2004), 'On the Determinants of Pyramidal Ownership: Evidence on Dilution of Minority Interests', EFA 2004 Maastricht Meetings Paper, 4592

Barclay M., Holderness C. (1989), 'Private Benefits of Control of Public Corporations', Joumal of Financial Economics, 25, 371-95

Banfield E. C. (1967), Moral Basis of a Backward Society, Free Press

Bebchuk A. L. (1999), 'A Rent-Protection Theory of Corporate Ownership and Control', Stanford Law Review, 52, 127-170

Bebchuk A. L., Roe J. M. (1999), 'A Theory of Path Dependence in Corporate Ownership and Governance', working paper, Harvard Law School. 
Bebchuk L. A. et al. (2002), 'Managerial Power and Rent Extraction in the Design of Executive Compensation', University of Chicago Law Review, 69, 751-846

Bebchuk L., Grinstein Y. (2005), 'The Growth of Executive Pay', Oxford Review of Economic Policy, 21(2), 283-303

Ben Amar W. , André P. (2006), 'Separation of Ownership from Control and Acquiring Firm Performance: The Case of Family Ownership in Canada', Journal of Business Finance and Accounting, 33, 517-543

Berton de Marigny P. F. (1980), The Invasion of Canada, Toronto, McClelland and Stewart

Berton de Marigny P. F. (1982), Why We Act Like Canadians, McClelland \& Stewart

Bozec Y., Laurin C. (2004), 'Concentration des droits de propriété, distribution des droits de vote and performance opérationnelle des sociétés: une étude canadienne', le Finance Contrôle Stratégie, 7, 123-64

Bozec Y. Laurin C. (2006), 'Separating Voting Rights from Cash-flow Rights and Entrenchment Agency Problem: Empirical Evidence from Canada', working paper

Bozec Y., Rousseau S., Laurin C. (2006), 'Law of Incorporation and Firm Ownership Structure: The Law and Finance Theory Revisited', working paper

Becht M., Roell A. (1999), 'Blockholding in Europe: An International Comparison', European Economic Review, 43, 1049-1056

Bliss M. (1986), Northern Enterprise - Five Centuries of Canadian Business, McClelland and Stewart, Toronto

Chandler A. D. (1977), The Visible Hand, Cambridge, Mass. and London, England, The Belknap Press of Harvard University Press

Claessens S. et al. (2002), 'Disentangling the Incentive and Entrenchment Effects of Large Shareholders', Journal of Finance, 57, 2741-71

Cohen A. (2007), The Unfinished Canadian: The People We Are, McClelland \& Stewart

Curtis J. M., Sydor A. (2006), 'NAFTA@10', Office of the Chief Economist, Foreign Affairs and International Trade Canada, http://www.international.gc.ca/eet/research/nafta-en.asp

Dechow P., Sloan R. (1991), 'Executive Incentives and the Horizon Problem', Journal of Accounting and Economics, 14(1), 51-89

Demsetz H. (1983), 'The structure of ownership and the theory of the firm', Journal of Law and Economics, 26, 375-390

Demsetz H., Lehn K. (1985), 'The Structure of Corporate Ownership: Causes and Consequences', Journal of Political Economy, 93, 1155-77

Denis D. K., McConnell J. J. (2003), 'International Corporate Governance', Journal of Financial and Quantitative Analysis, 38, 1-37.

Dyck A., Zingales L. (2004), 'Private Benefits of Control: An International Comparison', Journal of Finance, 59, 2, 537-600

Eckbo E., Thorburn K. (2000), 'Gains to Bidder Firms Revisited: Domestic and Foreign Acquisitions in Canada', Journal of Financial and Quantitative Analysis, 35, 1-25.

Faccio M., Lang H.P. L. (2002), 'The Ultimate Ownership of Western European Corporations', Journal of Financial Economics, 65, 365-395

Fama E. (1980), 'Agency Problems and the Theory of the Firm', Journal of Political Economy, 88(2), 288-307

Francis D. (1986), Controlling Interest: Who Owns Canada, Macmillan Canada

Francis D. (2008), Who Owns Canada Now? Old Money, New Money and the Future of Canadian Business, Harper Collins Canada 
Fukuyama F. (1996), Trust: The Social Virtues and the Creation of Prosperity, Free Press

Galbraith J. K. (1971), The New Industrial State, Houghton-Mifflin; 2d revised edition

Gadhoum Y. (2006), 'Power of Ultimate Controlling Owners: A Survey of Canadian Landscape', Journal of Management Governance, 10, 179-204

Holderness C., Sheehan D. (1988), 'The Role of Majority Shareholders in Publicly Held Corporations: An Exploratory Analysis', Journal of Financial Economics, 20(41), 317-346

Hufbauer G. C., Schott J. J. (2005), NAFTA Revisited: Achievements and Challenges, The Peterson Institute for International Economics

Hurtig M. (2003), The Vanishing Country: Is It Too Late to Save Canada?, McClelland \& Stewart

Jensen M., Meckling W. (1976), 'Theory of the Firm: Managerial Behavior, Agency Costs and Ownership Structure', Journal of Financial Economics, 3, 305-360

Jensen M., Murphy K. J. (1990), 'Performance Pay and Top-Management Incentives', Journal of Political Economy, 98(2), 225-64

Jensen M.C. (1993), 'Modern Industrial Revolution, Exit, and the Failure of Internal Control Systems', Journal of Finance, 48, 831-80

La Porta R., Lopez-De-Silanes F., Shleifer A. (1998), 'Law and Finance', Journal of Political Economy, 106, 1113-55

La Porta R., Lopez-De-Silanes F., Shleifer A. (1999), 'Corporate Ownership Around the World', Journal of Finance, 54, 471-517

Mehran H. (1995), 'Executive Compensation Structure, Ownership, and Firm Performance', Journal of Financial Economics, 38(2), 163-84

Morck R., Stangeland D. A., Yeung B. (2000), 'Inherited Wealth, Corporate Control and Economic Growth: The Canadian Disease?', Concentrated Corporate Ownership, R. Morck (ed.), National Bureau of Economic Research, 319-69.

Morck R., Yeung B. (2003), 'Agency Problems in Large Family Business Groups', Entrepeneurship, Theory and Practice, 27(4), 367-82

Morck R. et al. (2005), 'The Rise and Fall of the Widely Held Firm: A History of Corporate Ownership in Canada', A History of Corporate Governance Around the World, Randall Morck (eds.), University of Chicago Press

Morck R., Yeung B. (2006), 'Some Obstacles to Good Corporate Governance In Canada and How to Overcome Them', study commissioned by the Task Force to Modernize Securities Legislation in Canada

Murphy K., Shleifer A., Vishny R. (1993), 'Why is Rent-seeking Costly to Growth?', American Economic Review, 82(2), 409-414

Murphy K. J. (1995), 'Politics, Economics, and Executive Compensation', University of

Cincinnati Law Review, 63(2)

Naylor R. T. (1975), History of Canadian Business 1867 -1914, James Lorimer \& Co. Toronto

Nenova T. (2003), 'The Value of Corporate Voting Rights and Control: A Cross-country Analysis', Journal of Financial Economics, 68, 325-51

Newman C. P. (1977), The Canadian Establishment, McClelland and Stewart-Bantam Ltd, Toronto.

Newman P. (1991), Merchant Princes, Penguin Viking

Newman P. (1998), Titans: How the New Canadian Establishment Seized Power, Viking

Norrie K., Owram D. (1991), A History of the Canadian Economy, Harcourt Brace Jovanovich, Canada

Olson M. Jr. (1963), 'Rapid Growth as a Destabilizing Force', Journal of Economic History, 23(4), 529-552 
Rajan R., Zingales L. (1998), 'Power in a Theory of the Firm', Quarterly Journal of Economics, 113, 387-432

Rajan R., Zingales L. (2003), 'The Great Reversals: The Politics of Financial Development in the Twentieth Century', Journal of Financial Economics, 69(1), 5-50

Rajan R., Zingales L. (2004), Saving Capitalism from the Capitalists: Unleashing the Power of Financial Markets to Create Wealth and Spread Opportunity, Princeton University Press

Rodrik D. (2007), One Economics, Many Recipes: Globalization, Institutions, and Economic Growth, Princeton University Press

Shleifer A., Vishny R. (1986), 'Large Shareholders and Corporate Control', Journal of Political Economy, 94, 461-488

Shleifer A., Vishny R. (1997), 'A Survey of Corporate Governance', Journal of Finance, 52, 737 83

Schwartz M. A. (1967), Public opinion and Canadian identity, University of California Press

Stulz R., Williamson R. (2003), 'Culture, Openness, and Finance', Journal of Financial Economics, 70(3), 313-349

Taylor G., Baskerville P. (1994), A Concise History of Canadian Business, Oxford University Press

Thomas D. (2007), Canada and the United States: Differences that Count, Broadview Press, 3rd edition

Tian G. (2006), Three Essays on Corporate Control in Canada, University of Alberta doctoral thesis in finance

Tullock G. (1967), 'The Welfare Costs of Tariffs, Monopolies, and Theft', Western Economic Journal (now Economic Inquiry), 5, 224-32

Warner D. F. (1960), The Idea of Continental Union: Agitation for the Annexation of Canada to the United States, 1849-1893, University of Kentucky Press

Weber M. (1904), The Protestant Ethic and the Spirit of Capitalism, Routledge

Weintraub S. (eds.) (2004), Nafta's Impact On North America: The First Decade, Center for Strategic \& International Studies

Yermack D. (1995), 'Do Corporations Award CEO Stock Options Effectively?', Journal of Financial Economics, 39(2-3), 237-69.

Yermack D. (1997), 'Good Timing: CEO Stock Option Awards and Company News Announcements', Joumal of Finance, 52(2), 449-476

Zingales L. (1994), 'The Value of the Voting Right: A Study of the Milan Stock Exchange Experience', Review of Financial Studies, 7,125-148 